\title{
A review on current trends and prospects in the pyrolysis of heavy oils
}

\author{
Odunayo T. Ore $^{1}$ (D) Festus M. Adebiyi ${ }^{1}$
}

Received: 14 November 2020 / Accepted: 25 January 2021 / Published online: 13 February 2021

(c) The Author(s) 2021

\begin{abstract}
Increasing global demand for energy is an aftermath of an upsurge in world population and industrialization. The exploration of heavy oils such as oil sands, tight oils, and heavy oils, is thus becoming a necessity in a bid to alleviating the energy crisis. The processing of fossil fuels using conventional methods is known to have devastating effects on global warming and ocean acidification. This has brought about innovation and development of environmental-friendly processing technologies. Of these processing technologies available to date, pyrolysis is the most widely employed due to low operating complexity and economic cost. As revealed by the reviewed studies, the distribution of products formed during pyrolytic processes is a function of residence time, heating rate, the temperature of reaction, and reactor design. The latter significantly influenced the qualitative and quantitative yield of products formed during pyrolysis. Operating conditions of temperature, pressure, and catalyst are also influential factors in determining the product yields. Most research efforts in the last 30 years have identified that optimum production of pyrolytic oils occurred between thermal cracking temperature of $350{ }^{\circ} \mathrm{C}$ and $500{ }^{\circ} \mathrm{C}$. The plausible mechanisms of pyrolysis are the free radical chain mechanism involving the homolytic cleavage of the $\mathrm{C}-\mathrm{C}$ bond, and the electron transfer mechanism. This review pointed out the current status of the adoption of pyrolysis by petroleum and petrochemical industries as a processing technology for low-value heavy oils into high-value light fractions. The findings of the studies reviewed can help for better understanding of the optimum pyrolysis conditions required for maximum production of oils and gases. It will also help in carefully choosing the most sustainable approach in a bid to averting economic and environmental risks.
\end{abstract}

Keywords Energy $\cdot$ Global warming $\cdot$ Heavy oils $\cdot$ Pyrolysis $\cdot$ Reactor design

\section{Introduction}

The global upsurge in population and industrialization has brought about a corresponding steady growth in the global demand for energy (Pacala and Socolow 2004; Cohen et al. 2011; Kumar et al. 2011; Sadeq et al. 2018; Al-Fatlawi et al. 2019). Between 1971 and 2017, the world energy consumption has increased by almost 3 times from 5519 to 13,972 Mtoe (IEA 2019). Fossil fuels represent the primary sources of energy and petrochemicals all over the world. However, there are economic and environmental issues associated with fossil fuels due to the increasing demand for energy. Specifically, ocean acidification and global warming have been attributed to the use of petroleum as fuel (CNN 2020).

Odunayo T. Ore

oreodunayo@yahoo.com

1 Department of Chemistry, Obafemi Awolowo University, Ile-Ife 220005, Nigeria
The exploitation of petroleum at a rate faster than its regeneration coupled with the fact that it is only naturally found in a small group of countries has led to a diversity in the sources of energy. While oil has experienced a significant decline in its contribution to the energy portfolio from 44 to $32 \%$ (Fig. 1), it still represents a major source of energy. As shown in Fig. 2, petroleum still accounts for about 37\% of the energy consumption in the United States of America (EIA 2020). In a bid to alleviating the energy crisis, increasing attention is turning to the exploration of heavy oils such as tight oil, oil sands, and oil shale (Holditch 2013; Islam 2014; Al-Marshed et al. 2015; Al-Fatlawi 2018; Ore and Adeola 2020).

Heavy oils refer to a type of petroleum that is difficult to recover from the reservoir due to their relatively higher viscosity and density (Al-Jawad and Hassan 2012; Speight 2013a, 2016). Usually, they are deficient in hydrogen but are rich in metals, sulphur, and carbon (Speight 2013b). However, the value of heavy oils would need to be increased 

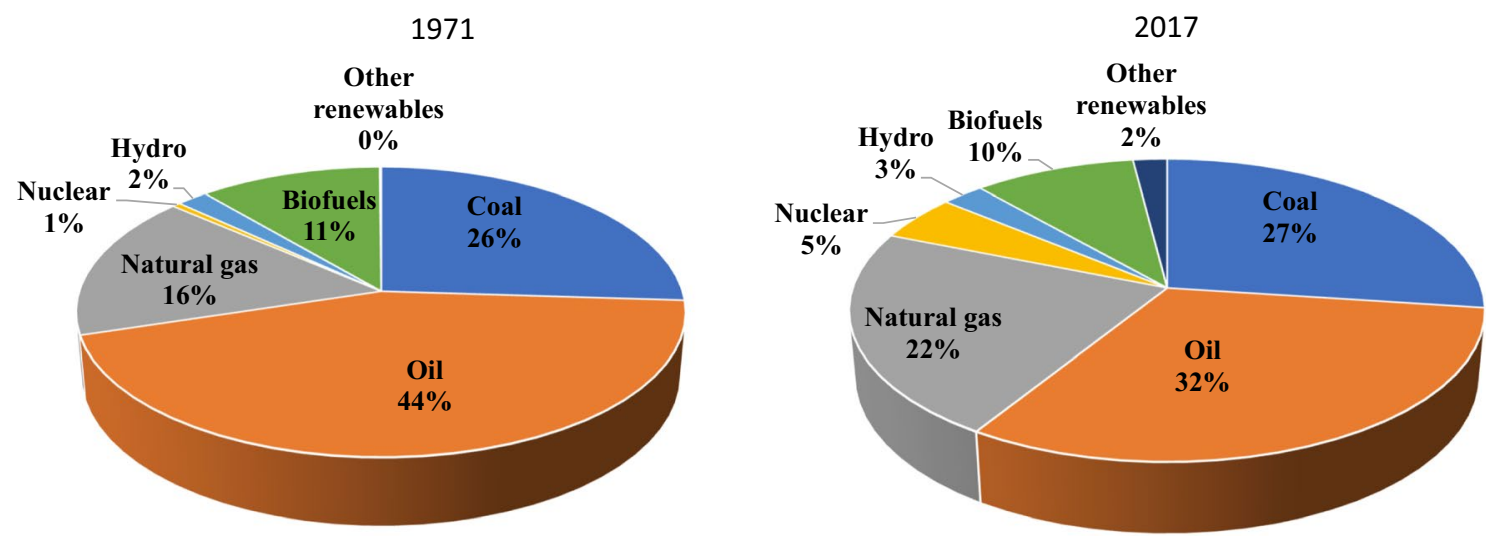

Fig. 1 Total primary energy supply by fuel in 1971 and 2017 (International Energy Agency 2019)

Fig. 2 Sources of primary energy consumed in the United States of America in 2019 (EIA 2020)

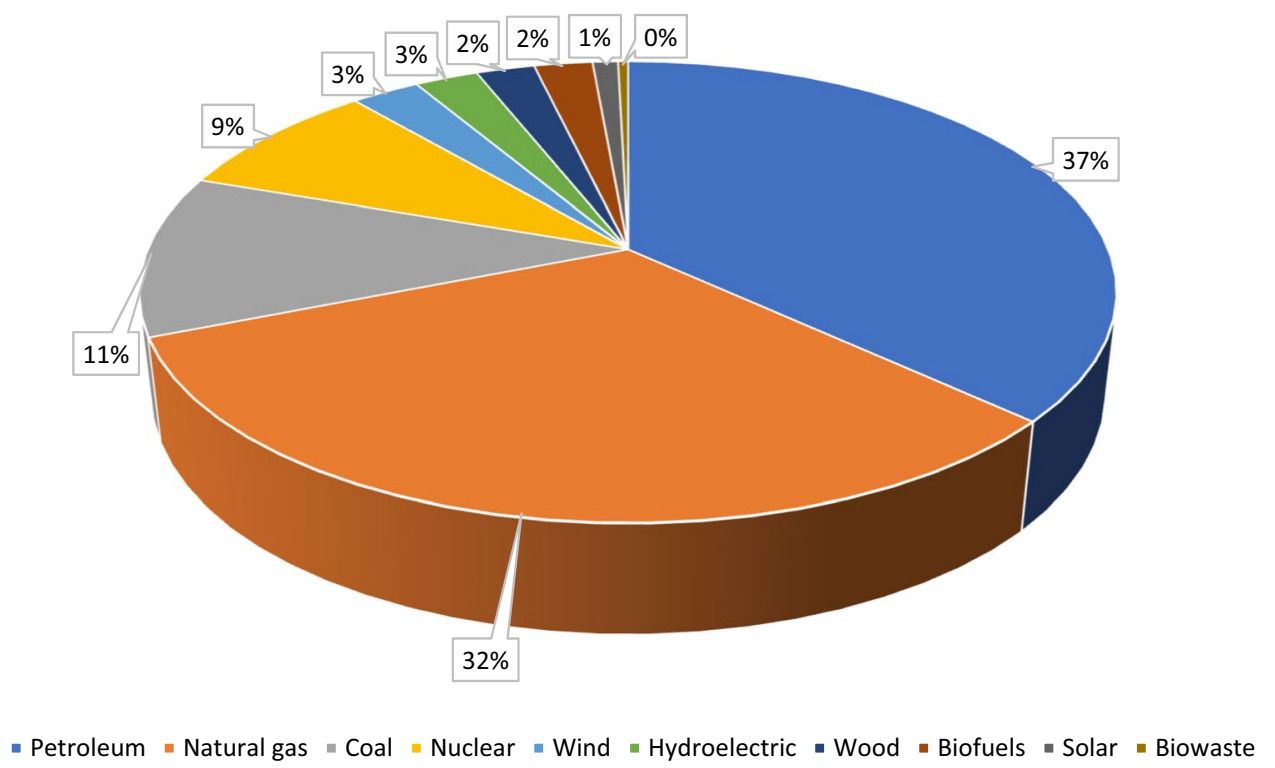

by the use of several upgrading technologies (Gray 2015). In addition to the reduction in viscosity, the use of these upgrading technologies would also be expected to mitigate the possible environmental risks associated with the exploitation and exploration of these heavy oils.

Conventionally, upgrading technologies are divided into separation, carbon rejection, and hydrogen addition processes. Usually, the latter produces more high-valued commercial products than the former. Nevertheless, high operating cost, among other factors, is a drawback for this technology (Speight 2011). A broad classification of upgrading technologies for heavy oils is shown in Fig. 3. The most popular upgrading technology is pyrolysis, due to its relatively low operational complexity and cost (Gray 2015). Pyrolysis is defined as the "thermal decomposition of materials usually accompanied by a change in chemical composition, at elevated temperatures in an inert atmosphere" (IUPAC 2009). The major concerns of the release of greenhouse gases such as nitrous oxide $\left(\mathrm{N}_{2} \mathrm{O}\right)$, methane $\left(\mathrm{CH}_{4}\right)$, and carbon dioxide $\left(\mathrm{CO}_{2}\right)$ are taken care of during pyrolysis.

Many studies have reported the use of pyrolysis as a processing technology for oil sands and oil shale (Shun et al. 2017; Jia et al. 2018; Nie et al. 2018; Tian et al. 2018; Chen et al. 2020; Kang et al. 2020). Many of these recent theoretical, field, and experimental studies were carried out under different reaction conditions, with a view to generating oils and gases. To the best of our knowledge, there is paucity of recent critical and comprehensive reviews on the pyrolysis of heavy oils despite an abundance of studies on the subject matter. This review aims to bridge information gaps on the fundamentals of pyrolysis as upgrading technology for heavy 


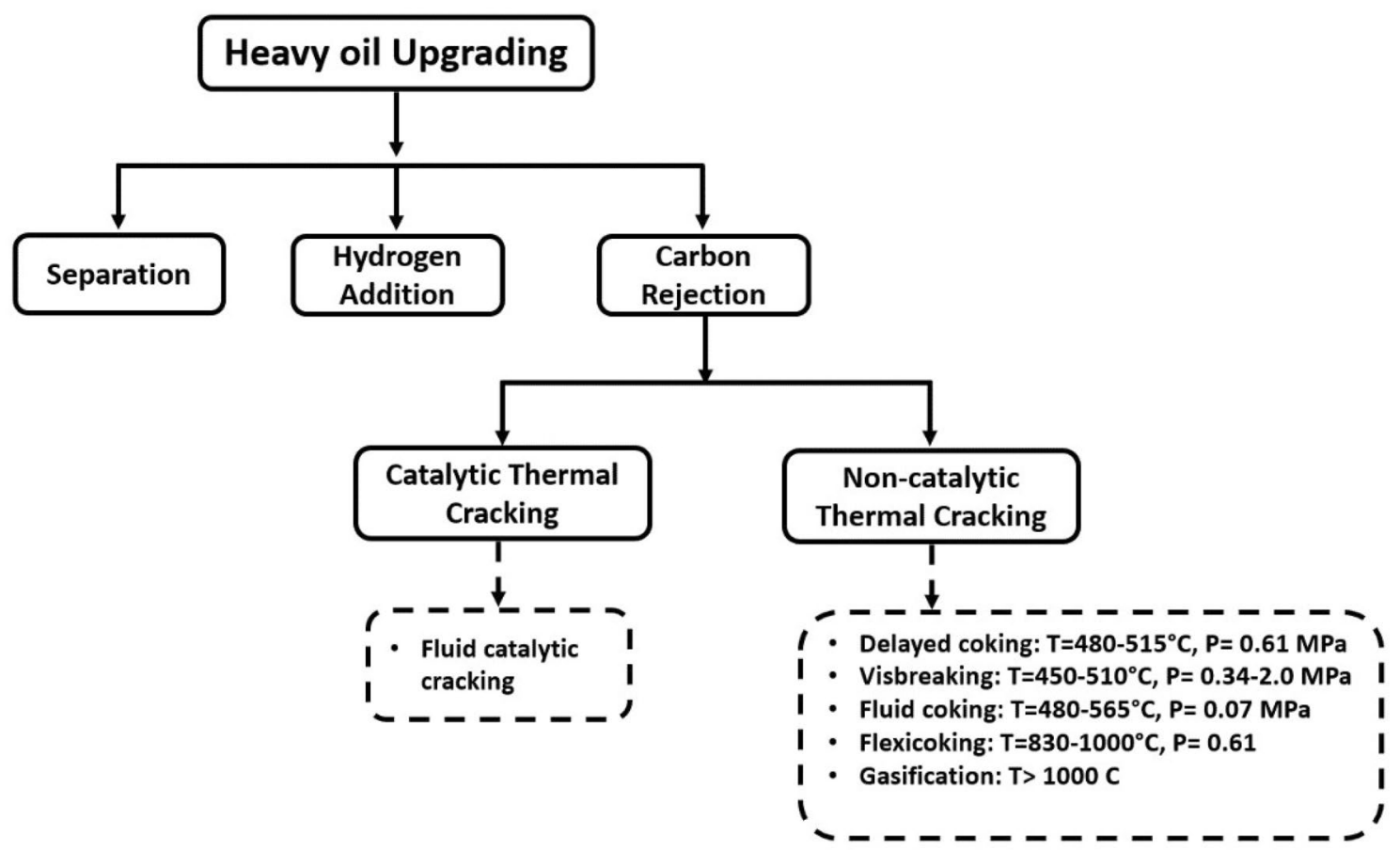

Fig. 3 Classification of the upgrading process of heavy oils (Gray 2015)

oils. First, the pyrolysis systems and reactors are described. Then, the reaction mechanisms of pyrolysis are illustrated. The effects of process conditions such as temperature and residence time on the composition and quality of pyrolytic oils and gases were also discussed.

\section{Pyrolysis systems and reactors}

Pyrolysis is an endothermic process. In other words, there is no exchange of heat between the system and the surroundings during the reaction, as a result of the inert atmosphere (Campuzano et al. 2019). The process can be slow, intermediate, fast, or flash depending on the residence time, heating rate, and heating temperature. A summary of the characteristics of the different pyrolysis systems is presented in Table 1. The residence time is longer for a slow pyrolysis system while a higher heating rate is employed for a fast pyrolysis system (Demibas and Arin 2002). A flash pyrolysis system is characterized by poor thermal stability resulting in the production of oils with quite high viscosity and residues (Cornelissen et al. 2008). Condensable liquids, uncondensing/permanent gases, and char are generally produced during pyrolysis (Anthe et al. 2015; Hui et al. 2014).

The determining factor for the quantitative and qualitative distribution of products during pyrolysis is the pyrolysis reactor design. Over the years, extensive research has focused on the development and use of several types of
Table 1 Summary of characteristics of pyrolysis process (Zaman et al. 2017)

\begin{tabular}{lllc}
\hline Pyrolysis types & Residence time & Heating rate & Temperature $\left({ }^{\circ} \mathrm{C}\right)$ \\
\hline Slow & $5-30 \mathrm{~min}$ & Low & 600 \\
Fast & $<2 \mathrm{~s}$ & Very high & 500 \\
Flash & $<1 \mathrm{~s}$ & High & $<650$ \\
Ultra-rapid & $<0.5 \mathrm{~s}$ & Very high & 1000 \\
Vacuum & $2-30 \mathrm{~s}$ & Medium & 400 \\
Carbonization & Days & Very low & 400 \\
Hydro-pyrolysis & $<10 \mathrm{~s}$ & High & $<500$ \\
\hline
\end{tabular}

reactors for pyrolysis (Bridgwater and Peacocke 2000). In a bid to maximize the yield of products during pyrolysis, the concept of heat supply and transfer is critical, and this is largely dependent on the configuration of the reactor as well as its operational conditions (Collard et al. 2016). The wide range of reactors commonly employed in pyrolysis includes rotatory kiln, batch, packed bed, Auger screw, rotating cone, fixed bed, fluidized bed, circulating fluidized bed, ablative, entrained flow, pyros, and plasma reactors. The configurations for some of the pyrolysis reactors are shown in Fig. 4.

\section{Fixed bed reactor}

Of all the available pyrolysis reactors, a fixed bed reactor is the simplest type to design as it consists of solid 


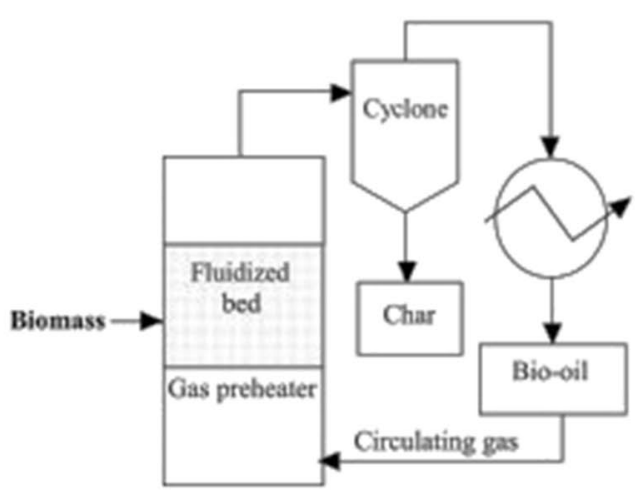

Fluidized bed reactor

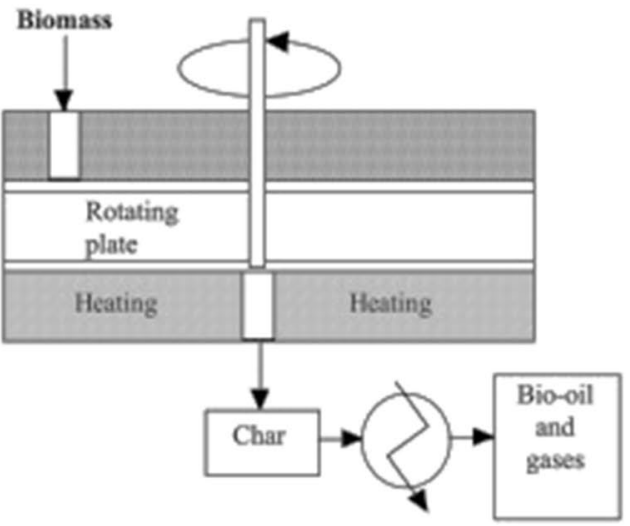

Ablative plate reactor

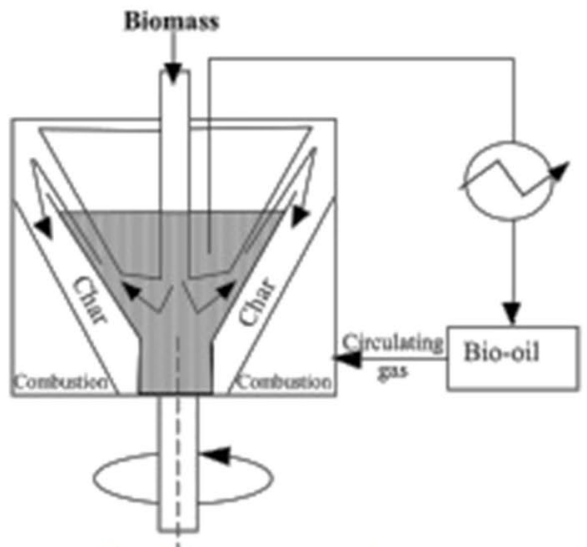

Rotating cone reactor

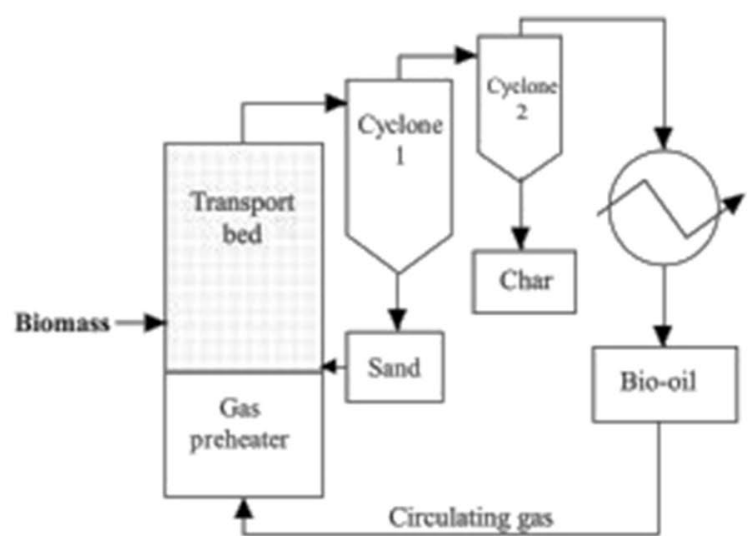

Circulating fluidized bed reactor

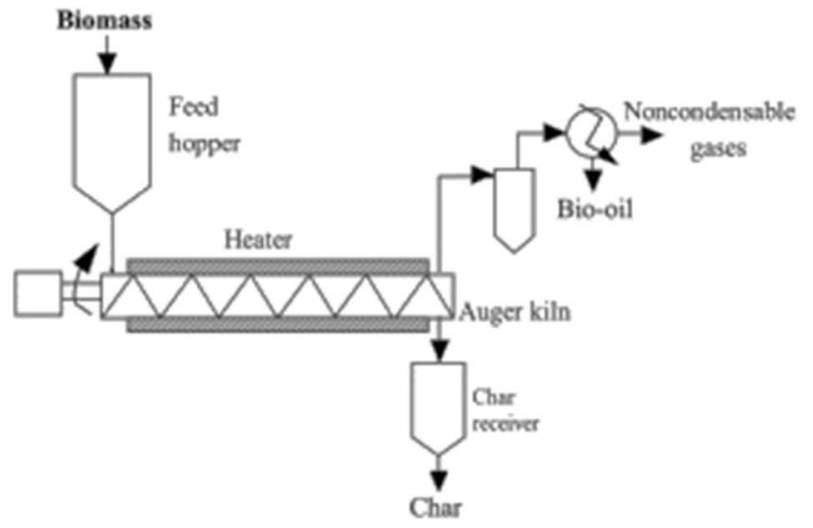

Auger/screw reactor

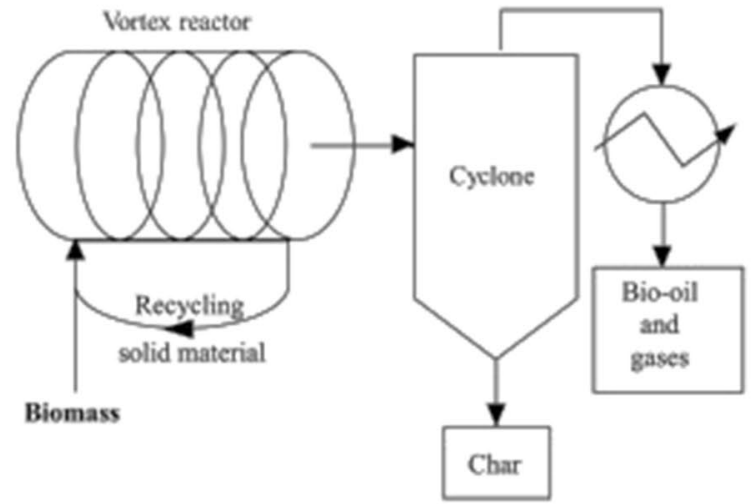

Cyclone/vortex reactor

Fig. 4 Configuration for different pyrolysis reactors (Dhyani and Bhaskar 2019)

catalysts being loaded and packed into a bed (Hafeez et al. 2019). This pyrolysis system comprises of a fixed bed reactor that pyrolyzes its feedstock in batches. It represents a reliable, simple, and effective technology for fuels with uniform size feedstocks. Despite the simplicity and flexibility of a fixed bed reactor, the non-economic batch nature of this pyrolysis system is its major drawback. In addition to this drawback, problems of declining catalyst productivity, low effectiveness factor, low heat transfer, temperature variations, and high viscosities are associated with the system (Wang and Economides 2009; Worstell 2014). Consequent upon this, they are only found useful 
in research and small-scale power applications (Jahirul et al. 2012).

\section{Fluidized bed reactor}

Fluidized bed reactors are the most mainstream setups utilized from the research facility to the business scale. These reactors are generally utilized in petroleum and petrochemi$\mathrm{cal}$ industries. The proficiency of fluidized bed reactors is attributed to the continuous nature of the input of feedstock as well as the production of oil. The commonly employed heat carriers in this pyrolysis system ensure a high and uniform rate of heat transfer, bringing about a high yield of oil in the process ( $\mathrm{Lv}$ et al. 2004). A "self-cleaning mechanism" is associated with this type of pyrolysis system, implying its ability to transport the produced char alongside gases out of the reactor. Cyclones are then employed in the separation process of the mixture prior to the condensation of the gases (Guda et al. 2015).

\section{Circulating fluidized bed reactor}

Operational similarities exist between fluidized bed reactors and circulating fluidized bed reactors (CFBs). However, while fluidized bed reactors employ a single heated reactor for the separation of char, CFBs utilize a second fluidized bed unit. The use of the second fluidized bed unit is to ensure that the produced char is combusted to produce thermal energy required by the first fluidized bed unit to achieve the pyrolysis process (Yang et al. 2007). The combustion of the char, which allows the return of the cleaned catalyst to the first fluidized bed unit, is aided by the incorporation of the second fluidized bed unit (Guda et al. 2015). CFBs are otherwise referred to as transport bed reactors due to the transportation of the heat carrier to the second fluidized bed unit and afterwards to the first fluidized bed unit. Their resourcefulness finds extensive applications particularly when the heat carrier has catalytic properties that enables the char to be glued to the surface of the catalyst (Guda et al. 2015). However, the drawbacks associated with the use of CFBs as opposed to fixed fluidized beds include fluidization problems, decreased capacity, high catalyst attrition, and higher construction costs, among others (Lappas and Heracleous 2016).

\section{Rotating cone reactor}

The rotating cone reactor accomplishes pyrolysis by infusing the particulate heat carrier blended in with the feedstock into the lower part of a heated cone pivoting at high revolutions per minute. The radiating power created by the rotating cone brings the blend of heat carrier and feedstock into close contact with the warmed surface of the cone. This personal contact delivers the pyrolysis reaction. The pivoting cone's radiating power additionally makes the particulate combination move to the top of the warmed cone. As the solids spill over the head of the cone, pyrolysis fumes are channeled to a condenser. The heat carrier and char mixture are shipped off to a fluidized bed combustor where the char is combusted from the heat carrier. This reactor configuration is extremely intricate because of the requirement for a coordinated activity including the riser for heat carrier recycling, fluidized bed char combustor, and a rotating cone pyrolyzer (Bridgwater and Peacocke 2000).

\section{Ablative pyrolysis}

Conceptually, ablative pyrolysis is different from other fast pyrolysis methods. A large number of pyrolysis processes require a high rate of heat transfer to determine the rate of reaction, thus needing little quantity of feedstock. Ablative pyrolysis, on the other hand, is dependent on the transfer of heat from the reactor wall upon contact with the feedstock. This way, the rate of reaction is not regulated by the transfer of heat directly through the feedstock. An advantage of this process is the fact that large feedstock sizes can be processed by an ablative reactor (Bridgwater and Peacocke 2000). However, the prevalent problem with an ablative pyrolysis reactor is its difficulty in the transfer of heat from gases to the ablative surface. In the process, feedstocks of diverse structure, density, and particle shape would experience difficulty in making contact with the ablative surface (Wu et al. 2014).

\section{Entrained flow reactor}

Entrained flow reactors employ the use of high temperatures up to $1400{ }^{\circ} \mathrm{C}$, resulting in a high level of carbon conversion of the feedstock. This pyrolysis system entrains the feedstock in the carrier gas. Oxygen is the most preferred oxidant for these reactors (Basu 2013). The particles entrained in the carrier gas are then fed into the reactor tube which is heated from the outside. Depending on how the fuel is injected into the reactor, they are usually of two types. The fuel and the carrier gas could enter from the top or from the side. Upon contact with the walls of the reactor tube, the heat conducted through the carrier gas pyrolyzes the feedstock as it flows down the tube. The pyrolytic gases are then transported to a condensation unit to be converted to liquid products, while the char is collected upon downward delivery by gravity (Arseneau 1971).

\section{Auger reactor}

Augers have found extensive use in the conveying and processing of feedstocks in the industry. Heat transfer and

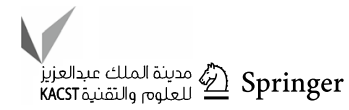


particle mixing are the other functions carried out by a properly designed auger. Good axial dispersion resulting in a higher uniformity of feedstock particles is aided by auger reactors (Nachenius et al. 2015). The major advantages of auger pyrolysis reactors are its suitability to use heat carriers in ensuring uniform and complete heat transfer, insensitivity to hydrodynamic bed conditions, and simplicity of design, operation, and maintenance. Its major drawback as opposed to ablative and CFBs configuration, though, is its requirement of a higher residence time for the release of gases (Campuzano et al. 2019).

\section{Plasma pyrolysis}

Plasma pyrolysis can be defined as "the process of reacting a carbonaceous solid with limited amounts of oxygen at high temperature to produce gas and solid products". A fast pyrolysis reaction occurs here due to the use of high temperatures. The hot plasma field is created by a high voltage electrical field. Upon injection, the feedstock is rapidly heated by the plasma, cracking the volatile matter, and giving rise to lighter hydrocarbons and hydrogen. The use of plasma pyrolysis reactors is limited due to high operating costs, a large amount of heat generated and released, and high use of electric power (Tang and Huang 2005).

\section{Reaction mechanisms of pyrolysis}

Pyrolysis generally brings about a significant reduction of the boiling point and molecular weight of the feedstock. The chemistry of this transformation from heavier molecules to lighter products is extremely complex. The principle of transformation of the heavy oil feedstock occurs via two basic mechanisms, namely the free radical chain mechanism and electron transfer mechanism. Pyrolytic reactions are thermally driven, hence there is no selectivity in bond cleavage; bonds with the weakest dissociation energies break first (Heck and Diguiseppi 1994). During pyrolysis, the chemical reactions occurring include homolytic cleavage of $\mathrm{C}-\mathrm{C}$ bonds, side-chain fragmentation (cleavage), ring growth, hydrogen shuttling, hydrogenation of aromatics/dehydrogenation of cycloparaffins, ring-opening, and heteroatom and metals removal (Rahimi and Gentzis 2006).

However, the most vital reaction is the homolytic cleavage of the $\mathrm{C}-\mathrm{C}$ bonds. The reaction mechanism for the $\mathrm{C}-\mathrm{C}$ bond cleavage proceeds through a free radical mechanism (Gray 1994). The free radical chain mechanism for a hypothetical molecule is shown in Fig. 5. The chain initiation step is characterized by the decomposition of the heavy molecule into two free radicals. The propagation step occurs via hydrogen transfer mechanism while the reaction is terminated via the reaction of two free radicals to form lighter products (Parsons 2000).

An alternative mechanism to cleavage of the homolytic $\mathrm{C}-\mathrm{C}$ bond is the electron transfer mechanism. Here, an electron is transferred from an aromatic core of a molecule to a metal $(\mathrm{Ni}, \mathrm{V}$, or $\mathrm{Fe})$ to produce a radical cation. While it was argued that the $\mathrm{C}-\mathrm{C}$ bond cleavage is predominantly caused by a radical hydrogen transfer mechanism, it is also possible that this electron transfer may occur during heavy oil upgrading since there is a significant concentration of transition metals capable of accepting electrons from highly condensed poly aromatics (Rahimi and Gentzis 2006).

\section{Current status and future prospects of heavy oil pyrolysis}

Khan (1988) employed the use of a fixed-bed reactor in generating pyrolytic liquids from coal, oil shale, and tar sand at $500{ }^{\circ} \mathrm{C}$. Differences in yield and composition exist among the products of the pyrolysis process. Results revealed that the obtained oil from the pyrolysis of the tar sand contained relatively large amounts of saturates, while the oil from the pyrolysis of coal contained relatively more aromatics. The relative richness of the tar sand oil in tetra- and penta-cyclic alkanes makes them suitable feedstocks for the production of aviation fuels.

The use of a rotary kiln pyrolysis reactor in the pyrolysis of Utah oil sand was reported by Hanson et al. (1992). The experiments were conducted using variable operating temperatures between 475 and $575{ }^{\circ} \mathrm{C}$ and reaction times between 10 and $27 \mathrm{~min}$. The liquid yield decreased and has yield increased with increasing reaction temperature. The contents of metals and heteroatoms in the liquid product were relatively lower than that of native bitumen, indicating that they were deposited with the residue during the pyrolysis process.

Slow and flash pyrolysis was conducted on Goynuk oil shale up to $550{ }^{\circ} \mathrm{C}$. Upon comparison of pyrolytic products with those extracted with supercritical water, lower contents of polar compounds and asphaltene were observed in the pyrolytic oils. Flash pyrolysis gave about $42 \%$ aromatics, while slow pyrolysis yielded more aliphatics (43\%). This confirmed that product composition is strongly dependent on the rate of pyrolysis (Yanik et al. 1995).

Nazzal et al. (2001) reported a study on the pyrolysis of Jordan oil shale in a fixed-bed reactor between 400 and $620{ }^{\circ} \mathrm{C}$. An increase in the temperature up to $520^{\circ} \mathrm{C}$ increased oil yield. Further increase in temperature caused a decrease in oil yield. The alkene/alkane ratio of the products increased with increasing temperature, hence, can be used as an indicator of pyrolysis temperature. 
Fig. 5 Free radical mechanism for the pyrolysis of a hypothetical molecule

\section{Initiation}

Propagation

Termination
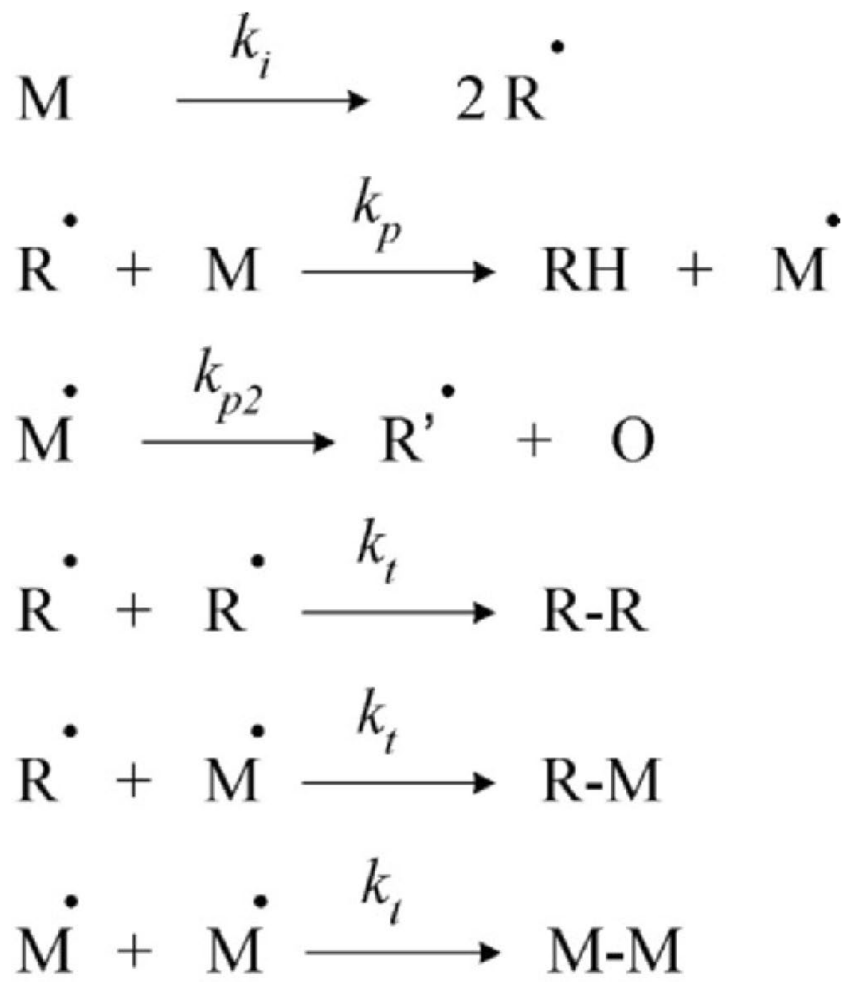

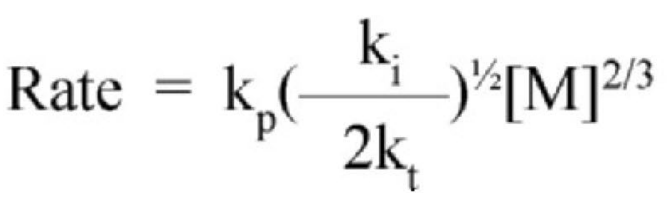

Liushuhe oil shale was pyrolyzed in the presence of water using a laboratory autoclave between 275 and $370{ }^{\circ} \mathrm{C}$. The pyrolysis process yielded shale gas, shale oil, residue, and pyrobitumen. The pyrobitumen was further pyrolyzed and it yielded more residue, shale gas, and shale oil. The yield of pyrobitumen first reached a maximum and then begins to decrease to almost zero, with an increase in temperature (Fang et al. 2012).

The pyrolysis of oil sand bitumen was investigated in the presence of water and toluene at $430{ }^{\circ} \mathrm{C}$. The rate of coke formation was found to be higher via the addition of water in the presence of toluene. However, the addition of toluene was discovered to decrease the rate of maltene degradation (Osato et al. 2012).

The reaction behaviour of Chinese oil sand was investigated using a fluidized bed pyrolysis reactor between $450-530{ }^{\circ} \mathrm{C}$ and $2-10 \mathrm{~min}$. Results indicated that products formed increased with increasing reaction time, up to a maximum of $5 \mathrm{~min}$, suggesting the completion of the pyrolysis reaction within $5 \mathrm{~min}$. The maximum yield of liquid products was obtained at $490^{\circ} \mathrm{C}$. It was reported that the defining parameters for a pyrolysis process are reaction temperature and time (Gao et al. 2013).

Jia et al. (2018) carried out pyrolysis of oil sand in a vertical fixed bed reactor between 200 and $750{ }^{\circ} \mathrm{C}$ using different heating rates $\left(5,10\right.$, and $\left.20^{\circ} \mathrm{C} \mathrm{min}^{-1}\right)$. It was observed that the aliphatic chain becomes shorter while the branchedchain increases, with an increase in temperature. $\mathrm{CO}_{2}, \mathrm{CH}_{4}$, $\mathrm{H}_{2}$, and $\mathrm{CO}$ were the major gases evolved upon pyrolysis. The hydrogen gas produced upon pyrolysis has been attributed to be mainly from the dehydrogenation of hydrogenated aromatic rings under high temperature (Das 2001; Strezov et al. 2004).

Kazakhstan oil sands were pyrolyzed in a batch reactor from room temperature to $600{ }^{\circ} \mathrm{C}$ using different heating rates $\left(5,10,15\right.$, and $\left.20^{\circ} \mathrm{C} \mathrm{min}^{-1}\right)$. Results indicated that the heating rate affected mass loss but shortened the time of decomposition of the oil sand. When the pyrolysis temperature exceeded $450{ }^{\circ} \mathrm{C}$, the aromatization reaction was favoured due to the dehydrogenation of the naphthene. As reported, this had a change on the alkane content of the fractions obtained upon pyrolysis (Fan et al. 2017). 
Gold-tube pyrolysis experiments were carried out on Athabasca oil sand bitumen between 300 and $525^{\circ} \mathrm{C}$ using a $2{ }^{\circ} \mathrm{C} / \mathrm{h}$ heating rate under $50 \mathrm{MPa}$. The generation of aromatic compounds at $425{ }^{\circ} \mathrm{C}$ was a major discovery in the study. The content of saturated and aromatic compounds decreased at temperatures higher than $450{ }^{\circ} \mathrm{C}$. Vaporization during pyrolysis was largely responsible for the loss of low molecular weight hydrocarbons (Li and Huang 2020).

Heavy crude oil was pyrolyzed at $380{ }^{\circ} \mathrm{C}$ and 32 bar for $2 \mathrm{~h}$ using $\mathrm{Ni}-\mathrm{Co} / \gamma-\mathrm{Al}_{2} \mathrm{O}_{3}$ catalyst in a Parr batch reactor. The reaction was carried out in both nitrogen and hydrogen environments. It was observed that the use of the catalyst showed more marketable components in the resulting light oil than with thermal cracking. Also, more pyrolytic gases were generated under a hydrogen environment than a nitrogen environment. This was attributed to a reaction between the protons and the single or double carbon bonds to form light hydrocarbon gases (Avbenake et al. 2020).

This review is a clear indication that the choice of pyrolysis system and/or reactor influences the composition and quality of product yields. The economic cost might then be a suitable criterion to be considered in the selection of operating parameters and pyrolysis systems. Further research should be explored in removing the oxygen present in the gas phase of the pyrolytic products. The development of suitable catalysts for the upgrading of heavy oils is also recommended so as to reduce the residence time of the feedstock in the reactors. Highly efficient cost-effective reactors should also be developed in the future. Generally, the liquid products obtained from the pyrolysis of oil shale are unstable. They also contain significant amounts of nitrogen, sulphur, and oxygen-containing compounds, which makes it difficult for them to be used directly as liquid fuels. The quality of pyrolytic oils should be improved to meet specifications for use in the petroleum and petrochemical industry. Additional purification units for gases should be incorporated into pyrolysis reactors to make them useful as fuels. Although substantial evidence exists that the use of pyrolysis technology offers a reduction in the emissions of greenhouse gases, further assessment of environmental sustainability should be carried out to ensure compliance with environmental policies and guidelines.

\section{Summary and conclusions}

The depletion in the quantity of conventional crude in the limited number of petroleum-producing countries has awoken a growing interest in the upgrading of heavy oils. Of the available upgrading technologies, pyrolysis is the most widely used technology due to low operating costs. Pyrolysis is focused on the reduction of viscosity and removal of metals as well as nitrogen, sulphur, and oxygen-containing compounds. This is with a view to ensuring that the resulting products formed upon pyrolysis satisfy the varying specifications needed to meet energy needs.

Based on the findings of the reviewed studies, the following observations and recommendations are pointed out:

- The quality of products formed during pyrolysis varies due to differences in reactor designs and operating parameters of temperature, residence time, and heating rate.

- Some of the investigated pyrolysis systems can only be used at the laboratory scale currently, while many of them are already being employed on the industrial scale.

- Further developments should be geared towards improving the efficiency of existing technologies.

- The mitigation of ecological risks, largely down to greenhouse gases, should be a priority in considering future prospects for pyrolysis technology.

Funding The authors received no specific funding for this work.

\section{Compliance with ethical standards}

Conflict of interest The authors declare that they have no conflict of interest.

Open Access This article is licensed under a Creative Commons Attribution 4.0 International License, which permits use, sharing, adaptation, distribution and reproduction in any medium or format, as long as you give appropriate credit to the original author(s) and the source, provide a link to the Creative Commons licence, and indicate if changes were made. The images or other third party material in this article are included in the article's Creative Commons licence, unless indicated otherwise in a credit line to the material. If material is not included in the article's Creative Commons licence and your intended use is not permitted by statutory regulation or exceeds the permitted use, you will need to obtain permission directly from the copyright holder. To view a copy of this licence, visit http://creativecommons.org/licenses/by/4.0/.

\section{References}

Al-Fatlawi OF (2018) Numerical simulation for the reserve estimation and production optimization from tight gas reservoirs. Doctoral dissertation, Curtin University of Technology

Al-Fatlawi O, Hossain M, Patel N, Kabir A (2019) Evaluation of the potentials for adapting the multistage hydraulic fracturing technology in tight carbonate reservoir. In: SPE Middle East Oil and Gas Show and Conference. Society of Petroleum Engineers

Al-Jawad MS, Hassan OF (2012) Comprehensive model for flash calculations of heavy oils using the Soave-Redlich-Kwong equation of state. In: North Africa technical conference and exhibition. Society of Petroleum Engineers 
Al-Marshed A, Hart A, Leeke G, Greaves M, Wood J (2015) Effectiveness of different transition metal dispersed catalysts for in situ heavy oil upgrading. Ind Eng Chem Res 54(43):10645-10655

Anthe G, Turn SQ, Morgan TJ (2015) Fast pyrolysis behavior of Banagrass as a function of temperature and volatiles residence time in a fluidized bed reactor. PLoS ONE 10(8):e0136511. https ://doi.org/10.1371/journal.pone.0136511

Arseneau DF (1971) Competitive reactions in the thermal decomposition of cellulose. Can J Chem 49(4):632-638

Avbenake OP, Al-Hajri RS, Jibril BY (2020) Saturates and aromatics characterization in heavy crude oil upgrading using $\mathrm{Ni}-\mathrm{Co} / \gamma-$ $\mathrm{Al}_{2} \mathrm{O}_{3}$ catalysts. Pet Sci Technol. https://doi.org/10.1080/10916 466.2020.1779743

Basu P (2013) Gasification theory. Biomass Gasif Pyrolysis Torrefaction 2:199-248

Bridgwater AV, Peacocke GVC (2000) Fast pyrolysis processes for biomass. Renew Sustain Energy Rev 4(1):1-73

Campuzano F, Brown RC, Martínez JD (2019) Auger reactors for pyrolysis of biomass and wastes. Renew Sustain Energy Rev 102:372-409. https://doi.org/10.1016/j.rser.2018.12.014

Chen B, Han X, Tong J, Mu M, Jiang X, Wang S, Ye X (2020) Studies of fast co-pyrolysis of oil shale and wood in a bubbling fluidized bed. Energy Convers Manag 205:112356

CNN (2020) Drew Kann. Oil and gas production is contributing even more to global warming than was thought, study finds. CNN. Retrieved 17 Aug 2020. Accessed 23 Oct 2020

Cohen G, Joutz F, Loungani P (2011) Measuring energy security: trends in the diversification of oil and natural gas supplies. Energy Policy 39(9):4860-4869. https://doi.org/10.1016/j.enpol .2011 .06 .034

Collard FX, Carrier M, Görgens JF (2016) Fractionation of lignocellulosic material with pyrolysis processing. In: Mussatto SI (ed) Biomass fractionation technologies for a lignocellulosic feedstock based biorefinery. Elsevier, Amsterdam, pp 81-101

Cornelissen T, Yperman Y, Reggers G, Schreurs S, Carleer R (2008) Flash co-pyrolysis of biomass with polylactic acid. Part 1: influence on bio-oil yield and heating value. Fuel 87:1031-1041

Das TK (2001) Evolution characteristics of gases during pyrolysis of maceral concentrates of Russian coking coals. Fuel 80(4):489-500

Demibas A, Arin G (2002) An overview of biomass pyrolysis. Energy Source Part A 24:471-482

Dhyani V, Bhaskar T (2019) Pyrolysis of biomass. In: Pandey A, Larroche C, Dussap CG, Gnansounou E, Khanal SK, Ricke S (eds) Biofuels: alternative feedstocks and conversion processes for the production of liquid and gaseous biofuels. Academic Press, New York, pp 217-244

EIA (2020) Calculated with data from the report: "April 2020 Monthly Energy Review." U.S. Energy Information Administration, Office of Energy Statistics, 27 April 2020. www.eia.gov

Fan Q, Bai G, Wu S, Yuan W, Song XM (2017) The chemical structure and the kinetics research of oil-wet oil sand from Kazakhstan during pyrolysis process. Pet Sci Technol 35(14):1495-1501

Fang C, Li S, Ma G, Wang H, Huang Z (2012) Reaction mechanism and kinetics of pressurized pyrolysis of Chinese oil shale in the presence of water. Pet Sci 9(4):532-534

Gao J, Xu T, Wang G, Zhang A, Xu C (2013) Reaction behavior of oil sand in fluidized-bed pyrolysis. Pet Sci 10(4):562-570

Gray MR (1994) Upgrading petroleum residues and heavy oils. Edited by Heinz Heinemann. Chemical I. Marcel Dekker, New York

Gray MR (2015) Upgrading of oil sands bitumen and heavy oil. The University of Alberta Press, Edmonton

Guda VK, Steele PH, Penmetsa VK, Li Q (2015) Fast pyrolysis of biomass. Recent Adv Thermo-Chem Convers Biomass. https:// doi.org/10.1016/b978-0-444-63289-0.00007-7
Hafeez S, Pallari E, Manos G, Constantinou A (2019) Catalytic conversion and chemical recovery. In: Plastics to energy. William Andrew Publishing, pp 147-172

Hanson FV, Cha SM, Deo MD, Oblad AG (1992) Pyrolysis of oil sand from the Whiterocks deposit in a rotary kiln. Fuel 71(12):1455-1463

Heck RH, DiGuiseppi FT (1994) Kinetic and mechanistic effects in resid hydrocracking. Energy Fuels 8(3):557-560

Holditch SA (2013) Unconventional oil and gas resource development-let's do it right. J Unconv Oil Gas Resour 1:2-8

Hui Z, Chunfei W, Aihong M, Yanguo Z, Williams PT (2014) Effect of interactions of biomass constituents on polycyclic aromatic hydrocarbons (PAH) formation during fast pyrolysis. J Anal Appl Pyrol 110:264-269. https://doi.org/10.1016/j.jaap.2014.09.007

International Energy Agency (IEA) (2019) World Energy Balances 2019. https://www.iea.org/reports/world-energy-balances-2019. Accessed 26 Oct 2020

Islam MR (2014) Unconventional gas reservoirs: evaluation, appraisal, and development. Elsevier, Amsterdam

IUPAC (2009) "Pyrolysis". Compendium of Chemical Terminology, 2nd ed. (the "Gold Book"). Compiled by A. D. McNaught and A. Wilkinson. Blackwell Scientific Publications, Oxford (1997). Online version (2019-) created by S. J. Chalk. ISBN 0-96785509-8. https://doi:https://doi.org/10.1351/goldbook.P04961. p 1824

Jahirul M, Rasul M, Chowdhury A, Ashwath N (2012) Biofuels production through biomass pyrolysis-a technological review. Energies 5(12):4952-5001. https://doi.org/10.3390/en5124952

Jia C, Chen J, Bai J, Yang X, Song S, Wang Q (2018) Kinetics of the pyrolysis of oil sands based upon thermogravimetric analysis. Thermochim Acta 666:66-74

Kang Z, Zhao Y, Yang D, Tian L, Li X (2020) A pilot investigation of pyrolysis from oil and gas extraction from oil shale by in-situ superheated steam injection. J Petrol Sci Eng 186:106785

Khan MR (1988) Correlations between physical and chemical properties of pyrolysis liquids derived from coal, oil shale, and tar sand. Energy Fuels 2(6):834-842

Kumar S, Kwon H-T, Choi K-H, Hyun Cho J, Lim W, Moon I (2011) Current status and future projections of LNG demand and supplies: a global prospective. Energy Policy 39(7):4097-4104. https ://doi.org/10.1016/j.enpol.2011.03.067

Lappas A, Heracleous E (2016) Production of biofuels via FischerTropsch synthesis: biomass-to-liquids. In: Handbook of biofuels production. Woodhead Publishing, pp 549-593

Li ZX, Huang HP (2020) Bulk and molecular composition variations of gold-tube pyrolysates from severely biodegraded Athabasca bitumen. Pet Sci 17(6):1527-1539

Lv P, Xiong Z, Chang J, Wu C, Chen Y, Zhu J (2004) An experimental study on biomass air-steam gasification in a fluidized bed. Biores Technol 95(1):95-101. https://doi.org/10.1016/j.biort ech.2004.02.003

Nachenius RW, Van De Wardt TA, Ronsse F, Prins W (2015) Residence time distributions of coarse biomass particles in a screw conveyor reactor. Fuel Process Technol 130:87-95

Nazzal JM (2001) Gas evolution from the pyrolysis of Jordan oil shale in a fixed-bed reactor. J Therm Anal Calorim 65(3):847

Nie F, He D, Guan J, Li X, Hong Y, Wang L, Zhang Q (2018) Oil sand pyrolysis: evolution of volatiles and contributions from mineral, bitumen, maltene, and SARA fractions. Fuel 224:726-739

Ore OT, Adeola AO (2020) Toxic metals in oil sands: review of human health implications, environmental impact, and potential remediation using membrane-based approach. Energy Ecol Environ. https ://doi.org/10.1007/s40974-020-00196-w

Osato K, Kato SN, Aida TM, Watanabe M, Smith RL, Inomata H (2012) The pyrolysis of oil sand bitumen in the presence of water and toluene. Nihon Enerugi Gakkaishi/J Jpn Inst Energy 91(4):303-310

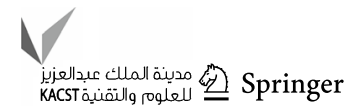


Pacala S, Socolow R (2004) Stabilization wedges: solving the climate problem for the next 50 years with current technologies. Science 305(5686):968-972

Parsons AF (2000) An introduction to free radical chemistry. WileyBlackwell, New York

Rahimi PM, Gentzis T (2006) The chemistry of bitumen and heavy oil processing. In: Hsu CS, Robinson PR (eds) Practical advances in petroleum processing. Springer, New York, pp 597-634

Sadeq D, Iglauer S, Lebedev M, Rahman T, Zhang Y, Barifcani A (2018) Experimental pore-scale analysis of carbon dioxide hydrate in sandstone via X-ray micro-computed tomography. Int J Greenh Gas Control 79:73-82

Shun D, Shin JS, Bae DH, Ryu HJ, Park J (2017) A comparison of fluidized bed pyrolysis of oil sand from Utah, USA, and Alberta, Canada. Korean J Chem Eng 34(12):3125-3131

Speight JG (2011) The refinery of the future. Gulf Professional Publishing Elsevier, Oxford

Speight JG (2013a) Heavy oil production processes. Gulf Professional Publishing, Oxford

Speight JG (2013b) Heavy and extra-heavy oil upgrading technologies. Gulf Professional Publishing, Elsevier, Oxford

Speight JG (2016) Introduction to enhanced recovery methods for heavy oil and tar sands. Gulf Professional Publishing, Oxford

Strezov V, Lucas JA, Strezov L (2004) Experimental and modelling of the thermal regions of activity during pyrolysis of bituminous coals. J Anal Appl Pyrol 71(1):375-392

Tang L, Huang H (2005) Plasma pyrolysis of biomass for production of syngas and carbon adsorbent. Energy Fuels 19(3):1174-1178
Tian Y, Li M, Lai D, Chen Z, Gao S, Xu G (2018) Characteristics of oil shale pyrolysis in a two-stage fluidized bed. Chin J Chem Eng 26(2):407-414

Wang X, Economides M (2009) Advanced natural gas engineering. University of Houston, Houston

Worstell J (2014) Adiabatic fixed-bed reactors: practical guides in chemical engineering. Butterworth-Heinemann, London

Wu LM, Zhou CH, Tong DS, Yu WH (2014) Catalytic thermochemical processes for biomass conversion to biofuels and chemicals. Bioenergy Res Adv Appl. https://doi.org/10.1016/b978-0-44459561-4.00015-2

Yang H, Yan R, Chen H, Lee DH, Zheng C (2007) Characteristics of hemicellulose, cellulose and lignin pyrolysis. Fuel 86(1213):1781-1788. https://doi.org/10.1016/j.fuel.2006.12.013

Yanik J, Yüksel M, Sağlam M, Olukçu N, Bartle K, Frere B (1995) Characterization of the oil fractions of shale oil obtained by pyrolysis and supercritical water extraction. Fuel 74(1):46-50

Zaman CZ, Pal K, Yehye WA, Sagadevan S, Shah ST, Adebisi GA, Marliana E, Rafique RF, Johan RB (2017) Pyrolysis: a sustainable way to generate energy from waste. In: Pyrolysis. BoD-Books on Demand, $\mathrm{p} 1$

Publisher's Note Springer Nature remains neutral with regard to jurisdictional claims in published maps and institutional affiliations. 